\title{
SISTEM PENDUKUNG KEPUTUSAN PENJURUSAN SISWA PADA SMA PANCAMARGA 1 LAMONGAN MENGGUNAKAN METODE FUZZY
}

\author{
Ahmad Fathoni' ${ }^{1)}$, Mustain ${ }^{2)}$, Retno Wardhani ${ }^{3)}$ \\ ${ }^{1)}$ Mahasiswa Program Studi Teknik Informatika, Fakultas Teknik, Universitas Islam Lamongan \\ ${ }^{2,3)}$ Dosen Program Studi Teknik Informatika, Fakultas Teknik, Universitas Islam Lamongan \\ Jl. Veteran No. 53 A Lamongan \\ Telp. (0322) 324706 \\ E-mail: ahmadfathoni982@gmail.com ${ }^{1}$,mustain@gmail.com²,retzno@yahoo.com ${ }^{3}$.
}

\begin{abstract}
Current majors are increasingly important when the institution will reposition. This means how the institution must know what factors affect the performance of teachers. The results of the analysis will be beneficial to make the education development program optimally and it is very necessary to advance the quality of education. Students need special attention from the government and society therefore the government regulates the improvement of the quality of teachers or teachers nationally through Law No. 20 of 2003 on National education system. In order to enforce the law, the government issued Regulation No. 19 of 2004 on the National Education standard. Therefore developed sebi student decision support system on the sma pancamarga 1 Lamongan using fuzzy.
\end{abstract}

\section{Keywords: Application of Employee Performance Assessmentl, SPK ( Fuzzy Method)}

\section{PENDAHULUAN}

Sistem Pendukung Keputusan atau Decision Support System (DSS) merupakan suatu sistem terkomputerisasi yang dirancang untuk meningkatkan efektivitas dalam pengambilan keputusan untuk memecahkan masalah yang bersifat semi terstruktur dan tidak terstruktur sehingga dalam proses pengambilan keputusan yang dilakukan dapat lebih berkualitas.

Universitas adalah pendidikan formal siswa di Indonesia khususnya pada lulusan SMA. Mereka memiliki keinginan yang cukup besar untuk terus melanjutkan pendidikanya ke jenjang yang lebih tinggi. Hal ini dapat di buktikan dengan relatif cukup banyaknya siswa lulusan SMA yang mengadu nasib dengan mengikuti ujian masuk Negeri. Banyak pula kasus siswa yang merasa tidak cocok dengan minatnya ketika telah memperoleh mata pelajaran di Universitas, dan akhirnya dia mencari jurusan lain yang sama atau bahkan juga berbeda sama sekali dengan apa yang telah dipilihnya. Situasi seperti ini berdampak pada besarnya biaya pendidikan yang terlanjur dikeluarkan, baik oleh orang tua siswa maupun pemerintah yang mensubsidi lembaga pendidikan tersebut. Hal lain yang juga berakibat negatif adalah waktu dan tenaga dari para siswa yang drop out atau pindah jurusan itu menjadi tidak efisien

Kalau pada penalaran monoton, sistem hanya memiliki satu aturan, pada Metode Fuzzy, sistem terdiri atas beberapa aturan. Karena menggunakan konsep dasar penalaran monoton, pada metode tsukamoto, setiap konsekuen pada aturan yang berbentuk IF-THEN harus direpresentasikan dengan suatu himpunan fuzzy dengan fungsi keanggotaan yang monoton. Output hasil inferensi dari tiap-tiap aturan diberikan secara tegas (crisp) bedasarkan $\alpha$-predikat (fire strength). Proses agregasi antar aturan dilakukan, dan hasil akhirnya diperoleh dengan menggunakan defuzzy dengan konsep rata-rata terbobot. Keunggulan sistem fuzzy yaitu dapat menerjemahkan pengetahuan dari pakar dalam bentuk aturan-aturan, namun biasanya dibutuhkan waktu yang lama untuk menetapkan fungsi keanggotannya. Berdasarkan latar belakang di atas, maka saya tertarik untuk melakukan penelitian berupa Aplikasi webside "Sistem Pendukung Keputusan Penjurusan Siswa pada SMA Pancamarga 1 Lamongan Menggunakan Metode Fuzzy"

Adapun tujuan dari penelitian ini adalah sebagai berikut:

a. Dapat menentukan jurusan yang tepat bagi siswa dengan berdasarkan hasil psikotes, minat dan rata-rata nilai yang di dapatkan oleh siswa bersangkutan.

b. Memberikan cara yang mampu mempercepat dalam penentuan jurusan bagi siswa.

Adapun manfaat dari penelitian ini adalah sebagai berikut:

a. Dapat menentukan jurusan yang tepat bagi siswa dengan berdasarkan kriteria yang ada.

b. Dapat memberikan cara untuk mempercepat dalam penentuan jurusan bagi siswa

Pemilihan jurusan dapat diartikan dasarnya merupakan faktor kunci guna mengembangkan suatu organisasi secara efektif dan efesien, karena adanya kebijakan atau program yang lebih baik atas sumber daya manusia yang ada dalam organisasi.

Penilaian kinerja individu sangat manfaat bagi dinamika pertumbuhan organisasi secara keseluruhan, melalui penilaian tersebut maka dapat diketahui kondisi sebenarnyatentang bagaimana kinerja pegawai.

Menurut Henry Simamora (1997, P. 415), pemilihan jurusan (performance appraisal) adalah proses dengannya organisasi mengevaluasi pelakasanaan kerja individu. Dalam penilaian 
kinerja dinilai kontribusi karyawan kepada organisasi selama periode waktu tertentu.

Umpan balik kinerja (performance feedback) memungkinkan karyawan mengetahui seberapa baik mereka bekerja jika dibandingkan dengan standar-standar organisasi. Apabila penilaian kinerja dilakukan secara benar, para karyawan, penyelia-penyelia mereka, departemen sumber daya manusia, dan akhirnya organisasi bakal diuntungkan dengan pemastian bahwa upaya-upaya individu memberikan kontribusi kepada fokus strategik organisasi dan pada saat ini sekolah sangat perlu sebuah sistem pendukung keputusan pemilihan rekomendasi jurusan.

PHP adalah bahasa skrip yang dapat ditanamkan atau disisipkan ke dalam HTML. PHP banyak di pakai untuk memrogram situs web dinamis. PHP dapat digunakan untuk membangun sebuah CMS.

Pada awalnya PHP merupakan kependekan dari Personal Home Page. PHP pertama kali dibuat oleh Rasmus Lordorf pada tahun 1995. Pada waktu itu PHP masih bernama Form Interpreted (FI), yang wujudnya berupa sekumpulan skrip yang digunakan untuk mengelolah data formulir dari web.

Selanjutnya Rasmus merilis kode sumber tersebut untuk umum dan menamakannya PHP/FI. Dengan merilis kode sumber ini menjadi sumber terbuka, maka banyak pemrogaman yang tertarik untuk ikut mengembangkan PHP.

Website atau situs dapat diartikan sebagai kumpulan halaman-halaman yang digunakan untuk menampilkan informasi teks, Gambar diam atau gerak, animasi, suara dan atau gabungan dari semuanya untuk itu baik yang bersifat statis maupun dinamis yang membentuk satu rangkaian bangunan yang saling terkait dimana masingmasing dihubungkan dengan jaringan-jaringan halaman (hyperlink).

Dalam pembuatan media informasi ini dengan website dikarenakan peneliti bertujuan agar informasi ini bisa langsung dinikmati oleh kalangan masyarakat.

Pada saat ini memang Mentri Pendidikan masih berpedoman wajib belajar sembilan tahun. Akan tetapi saat ini daya saing yang sangat tinggi akan dunia pekerjaan membuat manusia yang tingkat pendidikanya rendah hanya akan mendapat pekerjaan yang rendah pula, dikarenakan dunia pekerjaan lebih banyak melirik seseorang yang tingkat pendidikanya tinggi dan juga mempunyai wawasan yang luas. Semua itu bisa terjadi karna factor pendidikan di Indonesia bisa di bilang masih standar saja, maka dari itu sistem pendukung keputusan rekomendasi pemilihan jurusan ke universitas ini bisa di bilang adalah aplikasi terobosan guna membuat siswa sma pancamarga 1 Lamongan bisa mengetahui setidaknya apa jurusan yang bakan di pilih kelak jika mereka mau melanjutkan tingkat pendidikan yang lebih tinggi, guna menggunakan nilai rapor, minat,dan psikotes berarti mereka yang di lakukan pada siswa sma pancamarga 1 Lamongan.

Mamdani-FIS (Fuzzy Inference System) merupakan salah satu metode penalaran (inference) yang paling sering digunakan untuk persoalan kendalilogika fuzzy. Metode ini dikemukakan oleh Mamdani dan Assilian (1975) untuk mengendalikan mesin uap dan mendidihkan berdasarkan sintesis himpunan kendali aturan linguistic dengan percobaan operator seorang manusia. Metode sistem penalaran fuzzy Mamdani berdasarkan pada makalah Dr. Lofti Zadeh (1973) tentang algoritma fuzzy untuk sistem yang kompleks dan proses pengambilan keputusan. Kelebihan metode Mamdani dibandingkan metode sistem penalaran fuzzy yang lain, diantaranya adalah karena bersifat intuitif, mencakup bidang yang luas, dan sesuai dengan proses input informasi manusia. Sistem penalaran fuzzy metode Mamdani dikenal juga gabungan dari semuanya untuk itu baik yang bersifat statis maupun dinamis yang membentuk satu rangkaian bangunan yang saling terkait dimana masing-masing dihubungkan dengan jaringanjaringan halaman (hyperlink).dengan nama metode Max-Min yang akan lebih berpengaruh pada table.dan untuk lebih jelasnya keterangan dari rule masisng masing nilai akan dip roses di dalam program guna factor pendidikan di Indonesia bisa di bilang masih standar saja, maka dari itu sistem pendukung keputusan rekomendasi pemilihan jurusan ke universitas ini bisa di bilang adalah aplikasi terobosan guna membuat siswa membuat hitungan computer dan manual sama yaitu dengan menggunakan metode Fuzzy logic Mamdani yang akan di jelaskan di bawah ini:

Tabel 1. nilai Minmax

\begin{tabular}{cl}
\hline Kriteria Nilai & \multicolumn{1}{c}{ Keterangan } \\
\hline Jika if nilai ipa sangat baik nilai \\
ips sangat baik nilai mtk sangat \\
baik nilai miat sangat baik nilai \\
psikotes sangat baik then T.i \\
Jika if nilai ipa baik nilai ips \\
baik nilai mtk baik nilai minat \\
baik nilai psikotes baik then T.e
\end{tabular}


Penjurusan Fungsi keanggotaan adalah suatu kurva yang menunjukkan pemetaan titiktitik input data ke dalam nilai keanggotaannya yang memiliki interval antara 0 sampai salah satu cara yang dapat digunakan adalah dengan melalui pendekatan fungsi. Salah satu representasi fungsi keanggotaan dalam fuzzy yang akan dipakai adalah representasi linier. Pada representasi linier, pemetaan input ke derajat keanggotaannya diGambarkan sebagai suatu garis lurus. Bentuk ini paling sederhana dan menjadi pilihan yang baik untuk mendekati suatu konsep yang kurang jelas. Ada dua keadaan himpunan fuzzy yang linier. Pertama, kanaikan himpunan dimulai pada nilai domain yang memiliki derajat keanggotaan nol [0] bergerak ke kanan menuju ke nilai domain yang memiliki derajat keanggotaan lebih tinggi. Gambar grafik fungsi keanggotaannya adalah:

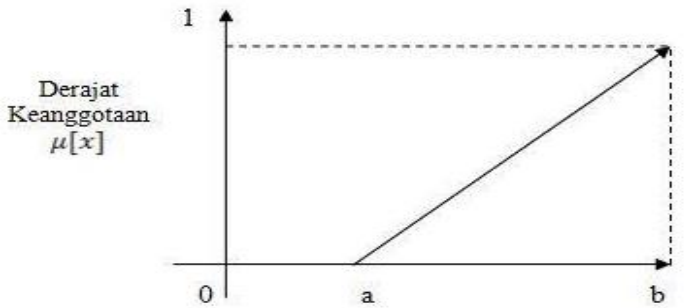

Keterangan:

$\mathrm{x}=$ Inputan keanggotaan

$\mathrm{a}=$ Batas nilai keanggotaan terendah

$\mathrm{b}=$ Batas nilai keanggotaan tertinggi

Kedua merupakan kebalikan yang pertama. Garis lurus dimulai dari nilai domain dengan derajat keanggotaan tertinggi pada sisi kiri, kemudian bergerak menurun ke niai lebih rendah. Gambar grafik fungsi keanggotaannya adalah:

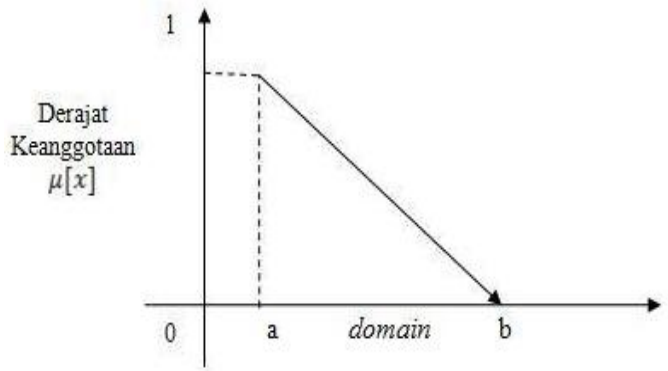

Metode fuzzy mamdani_banyak digunaka untuk penelitian tentang sistem cerdas. Sistem cerdas tersebut dapat berupa sistem pakar atau juga sistem pendukung keputusan (SPK). Keunikan dari metode ini adalah Penilaian dilakukan dengan menggunakan derajat keanggotaan. Derajat keanggotaan tersebut melipui nilai tentang suatu variabel berdasarkan tingkat linguistiknya. Variabel linguistik pada fuzzy yaitu nilai yang bersifat relativitas, misalnya tinggi, sedang dan pendek. sedangkan tingkatan nilai tersebutlah yang digunakan sebagai penilaian terhadap segitiga fuzzy yang bisa di lihat Metode mamdani adalah metode yang juga sering di kenal dengan metode $M A X-M I N$ atau MAX-PRODUCT. Metode $\mathbf{1 5 3} \mid \mathrm{P}$ a g e
Mamdani dikenal juga sebagai metode min-max, diperkenalkan oleh Ebrahim Mamdani pada tahun 1975. Menurut Djunaidi, Setiawan, dan Andista (2005). Adapun Gambaran pada Gambar rull IFTHEN sedangkan tingkatan nilai tersebutlah yang digunakan sebagai penilaian terhadap segitiga fuzzy yang bisa di lihat pada Gambar berikut:

Tahapan dan langkah-langkah metode fuzzy mamdani:

a. Pembentukan himpunan fuzzy

Pada metode Mamdani baik variabel input maupun variabel output dibagi menjadi satu atau lebih himpunan fuzzy. Contoh himpunan fuzzy ini miaslnya untuk nilai baik yaitu antara $7-10$, nilai sedang antara nilai $6-8$, dan nilai rendah antara $1-7$.

b. Aplikasi fungsi implikasi

Pada metode Mamdani, fungsi implikasi yang digunakan adalah minimum. Jadi dari nilai yang berupa himpunan fuzzy nilai yang digunakan sebagai implikasi adalah nilai MIN atau nilai yang paling terendah.

c. Komposisi aturan

Yang dimaksud komposisi aturan pada metode fuzzy adalah berupa cara-cara yang digunakan untuk menentukan penilaian himpunan fuzzy. Diantara beberapa metode yang dapat digunakan dalam melakukan komposisi aturan, yaitu metode max (maximum), additive, dan probabilistik OR seperti yang di jelaskan pada buku Kusumadewi dan Purnomo.

d. Penegasan (defuzzification)

Ini adalah langkah atau tahap terakhir pada sebuah fuzzy mamdani. Penegasan atau yang sering di kenal dengan defuzzification adalah proses mengolah suatu himpunan fuzzy yang diperoleh dari komposisi aturan-aturan fuzzy untuk menghasilkan output berupa suatu bilangan pada domain himpunan fuzzy tersebut. Menurut Kusumadewi dan Purnomo penulis dan pengarang buku tentang fuzzy.

Dan terdapat beberapa metode yang dapat digunakan pada defuzzify, metode fuzzyfikasi terebut diantaranya:

a. Metode Centroid (Composite Moment)

Pada metode centroid, titik pusat daerah fuzzy diambil untuk memperoleh solusi crisp.

b. Metode Bisektor Pada metode bisektor, nilai pada domain yang memiliki nilai keanggotaan separo dari jumlah total nilai keanggotaan pada daerah fuzzy diambil untuk memperoleh solusi crisp.

c. Metode Mean of Maximum (MOM) Pada metode mean of maximum, nilai rata-rata domain yang memiliki nilai keanggotaan maksimum diambil untuk memperoleh solusi crisp.

d. Metode Largest of Maximum (LOM) Pada metode largest of maximum, nilai terbesar dari domain yang memiliki nilai keanggotaan 
maksimum diambil untuk memperoleh solusi crisp.

e. Metode Smallest of Maximum (SOM) Pada metode smallest of maximum nilai terkecil dari domain yang memiliki nilai keanggotaan maksimum diambil untuk memperoleh solusi crisp.

Layaknya sebuah metode analisis, Fuzzy Interface Mamdani pun memiliki kelebihan dan kelemahan dalam system analisisnya. Kelebihankelebihan metode ini adalah:

a. Konsep logika fuzzy mudah dimengerti. Konsep matematis yang mendasari penalaran fuzzy sangat sederhana dan mudah dimengerti.

b. Logika Fuzzy sangat fleksibel.

c. Logika fuzzy memiliki toleransi terhadap datadata yang tidak tepat.

d. Logika Fuzzy mampu memodelkan fungsifungsi non linearyang sangat kompleks.

e. Logika fuzzy dapat membangun dan mengaplikasikan pengalaman-pengalaman

f. para pakar secara langsung tanpa harus melalui proses pelatihan.

g. Logika Fuzzy dapat bekerjasama dengan teknikteknik kendali secara konvensional.

h. Logika fuzzy didasarkan pada bahasa alami. Sedangkan kelemahan metode Fuzzy Mamdani adalah sebagai berikut:

a. Ketergantungan model Fuzzy Mamdani pada input utamanya. Input utama ini berupa persepsi seorang ahli sehingga dalam hal ini melibatkan subyektifitas sang ahli selain itu juga model menjadi tidak berarti jika ahli tersebut memberikan penilaian yang keliru.

b. Metode Fuzzy Mamdani ini hanya metode matematis tanpa ada pengujian secara statistik separo dari jumlah total nilai keanggotaan pada dalam hal ini melibatkan subyektifitas daerah fuzzy diambil untuk memperoleh solusi crisp sehingga tidak ada batas kepercayaan dari kebenaran model yang terbentuk.

\section{METODOLOGI PENELITIAN}

Dalam analisa perancangan proses adalah langkah awal dan langkah yang utama dalam membangun perangkat lunak dan juga sangat diperlukan karena proses ini menjelaskan alur berjalannya suatu program.

$>$ Blok Diagram

Tahapan perancangan sistem ini menggunakan Data Flow Diagram (DFD) level 0 dan level 1 sebagai berikut:

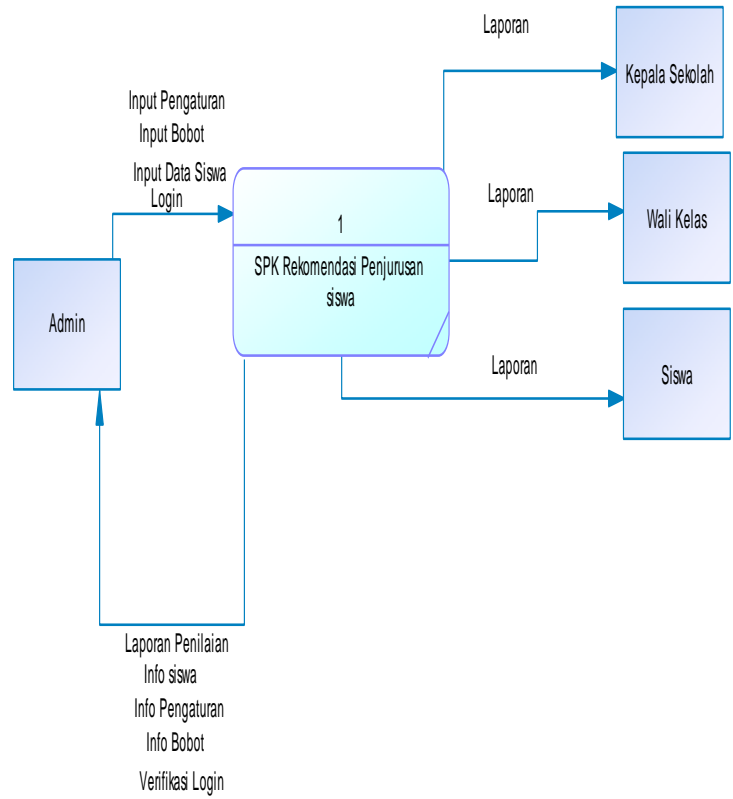

Gambar 1. DFD Level 0

\section{KETERANGAN:}

DFD level 0 ini adalah Gambaran umum dari sistem pendukung keputusan menentukan Rekomendasi pemilihan jurusan ke Universitas, Sistem ini memiliki 4 entity yaitu Admin, kepala sekolah, wali kelas, dan siswa,. Keempat Entity tersebut berpengaruh pada keberhasilan sistem untuk Membantu memberikan rekomendasi pemilihan jurusan . Penjelasan pengaruh entity pada sistem adalah sebagai berikut:

a. Admin atau Ahli adalah pihak yang bertugas melakukan input pengetahuan pada sistem. Kemampuan seorang administrator sekaligus sebagai peneliti merupakan faktor utama yang mempengaruhi berhasil atau tidaknya pembuatan sistem tersebut yang mempengaruhi keakuratan sistem dalam memecahkan masalah.

b. Kepala sekolah, siswa, walikelas, Mendapatkan hasil Laporan rekomendasi pemilihan jurusan ke universitas karena yang dapat memproses semuanya hanyalah Admin siswa hanya bisa melakukan persetujuan pada lembar persetujuan yang dibuat oeh (Guru BK).

\section{DFD (Data Flow Diagram)}

Diagram arus data digunakan untuk mengGambar suatu sistem baru yang akan dikembangkan secara logika tanpa mempertimbangkan lingkungan fisik dimana data tersebut mengalir. Adapun diagram arus data pada sistem pendukung keputusan ini adalah sebagai berikut. 


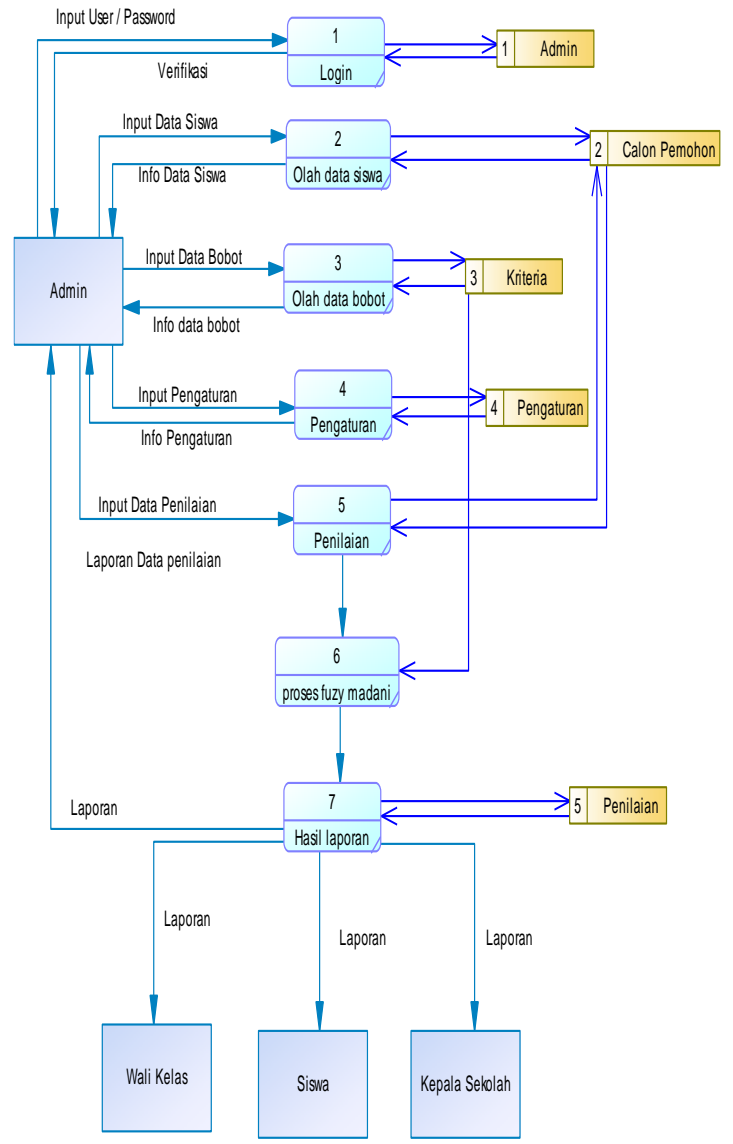

Gambar 2. DFD Level 1

\section{KETERANGAN:}

a. Admin memasukkan username dan password lalu akan mendapatkan verivikasi login.

b. Admin memasukkan input data siswa dan kemudian akan mendapatkan info data dari siswa.

c. Admin memasukkan bobot criteria dan mendapatkan info besar bobot kiteria

d. Admin memasukan nilai maksimum dari tiap jurusan dan administrator sekaligus sebagai peneliti merupakan faktor utama yang mempengaruhi berhasil atau tidaknya pembuatan sistem tersebut yang mempengaruhi keakuratan sistem dalam memecahkan masalah akan mendapatkan hasil dari nilai maksimum tiap jurusan

e. Admin menginputkan data siswa, minat dan nilai psikotes, setelah itu menuju proses deffuzifikasi (fuzzy mamdani) pada proses tersebut mengambil data pada subkriteria untuk data lebih lanjut.dan setelah terproses maka akan mendapatkan laporan yang akan di berikan kepada kepala sekolah,wali kelas, dan jugaa siswa.

\section{PEMBAHASAN}

\section{Halaman Login}

Pada halaman login ini admin akan di suruh mengisi from username dan from password, guna melakukan prosedur dalam sistem ini, dan akan di lihat pada Gambar 3.

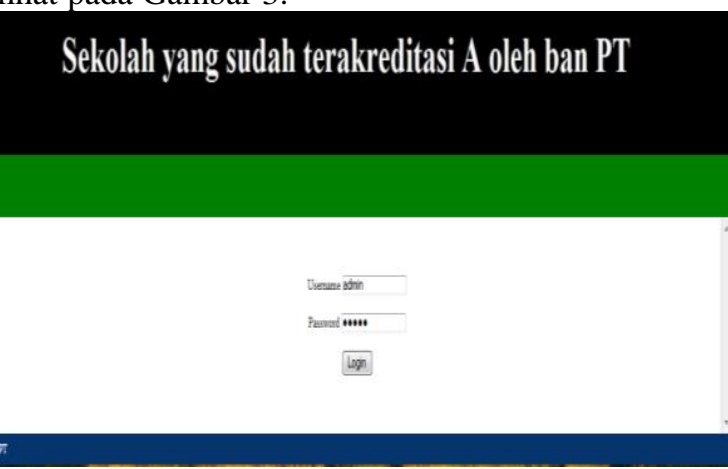

Gambar 3. Halaman Login

\section{Halaman Utama}

Pada halaman utama merupakan tampilan awal yang akan muncul jika web sistem pendukung keputusan penjurusan siswa pada Sma Pancamarga 1 Lamongan ini ketika pertama kali masuk seperti Gambar 4.

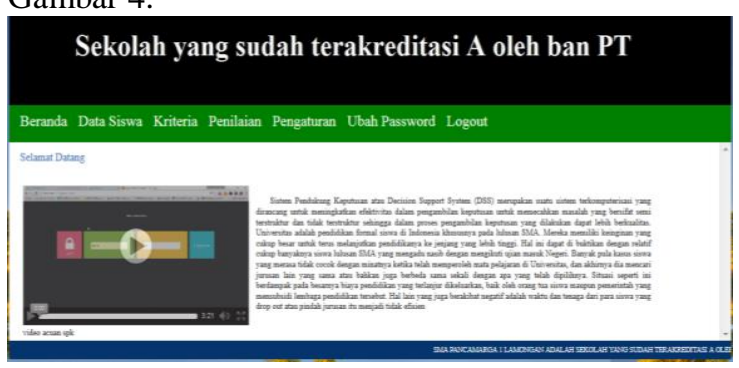

Gambar 4. Halaman utama

\section{Halaman Data Siswa}

Pada halaman data siswa akan memperlihatkan data siswa yang telah di input dan juga di olah oleh admin (Guru Bk ) yang sudah mengambil sampel dari beberapa siswa kelas XI. Dan data pada wb tersebut bisa diubah di website tanpa harus adanya mengubah database pad admin untuk data lebih lanjut.dan setelah terproses maka akan mendapatkan laporan yang akan di berikan kepada kepala sekolah Dan tampilan pada Gambar ini akan dapat di lihat pada Gambar 5.

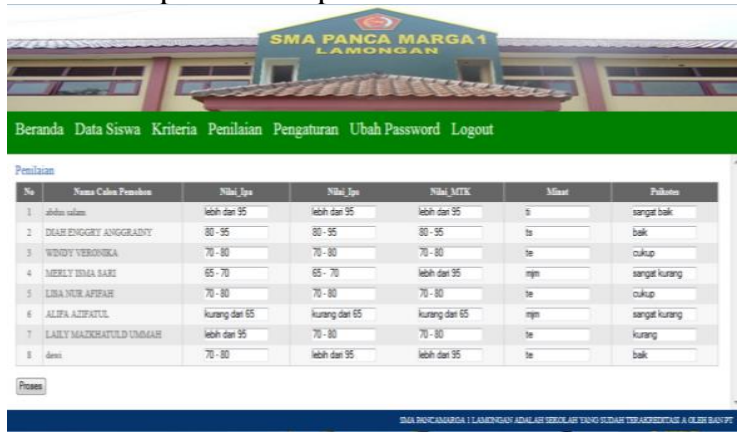

Gambar 5. data siswa

\section{Input Data siswa}

Adapun cara untuk menginputkan data siswa di atas adalah dengan melakukan penambahan data siswa yang ingin di inputkan nilainya adapun 
Gambar yang dapat dilihat guna menginputkan datanya adalah seperti Gambar 6 .

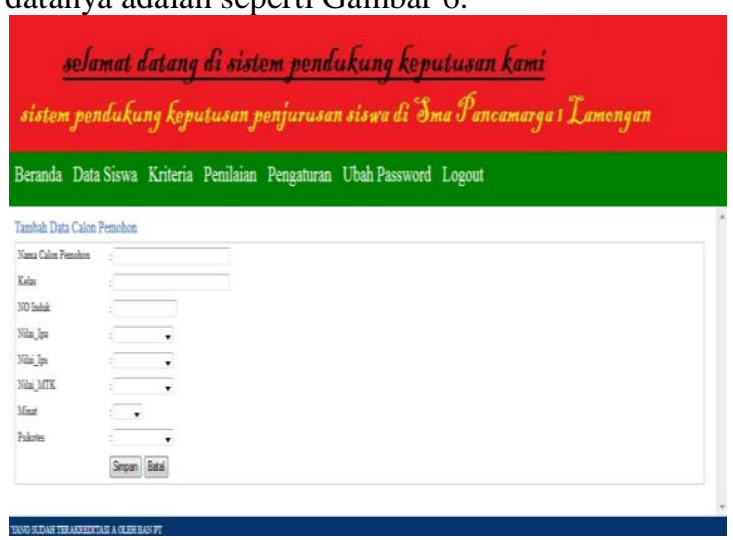

Gambar 6. Tambah data Siswa

\section{Halaman Proses Penilaian}

Pada halaman ini adaah bagian terpenting dari website ini, karena data dari semuanya baik dari nilai, minat dan psikotes akan di proses dengan menggunakan metode fuzzy mamdani dimana rull dari setiap bobot sub kriteria pada subkriteria untuk data lebih lanjut.dan setelah terproses maka akan mendapatkan laporan yang akan di berikan kepada kepala dan benar, adapun halaman dapat di lihat pada Gambar 7.

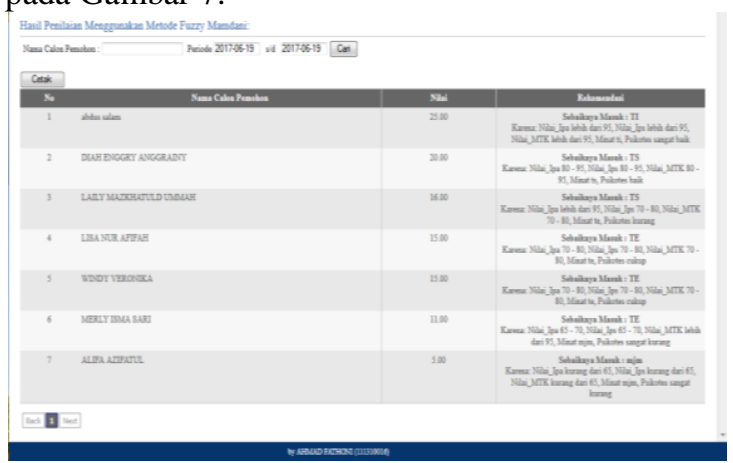

Gambar 7. Hasil Proses Penilaian

\section{Halaman Cetak Penilaian}

Pada halaman ini akan di lihatkan hasil cetak yang akan di berikan kepada kepala sekolah, wali kelas, dan juga siswa .Guna lihat hasil akan di perlihatkan pada Gambar 8.

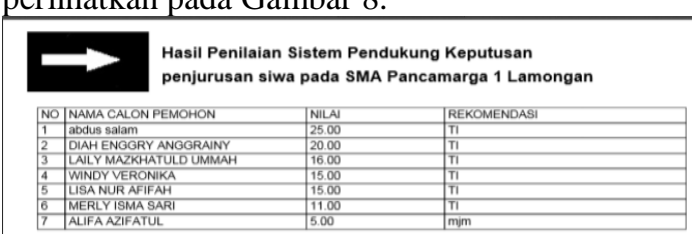

\section{Lamongan, 19-06-2017
Penanggung Jawab}

Gambar 8. Cetak Penilaian

\section{Halaman Pengaturan}

Pada halaman ini akan di Gambarkan bataas maksimum dan minimum nilai deffuzifikasi pada bobot dari nilai maksimum ti, te, ts, akun, dan juga manajemen kriteria adapun halaman akan di perlihatkan pada Gambar 9.

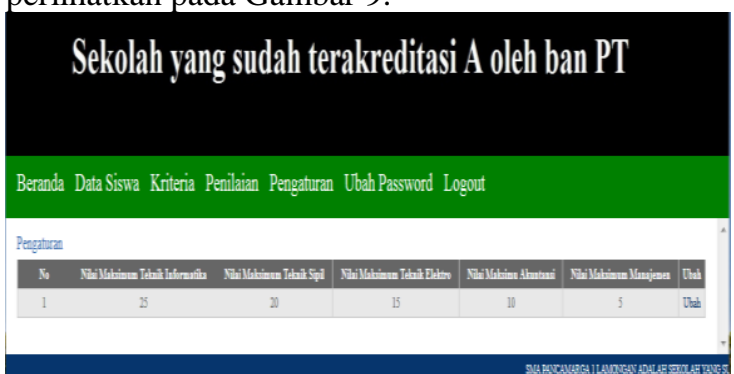

Gambar 9. Halaman Pengaturan

\section{Halaman Ubah Password}

Pada halaman ini akan di tampilkan ubah password otomatis tanpa merubah tatanan coding adapun cara untuk mengganti password adalah dengan memasukkan password lama untuk di masukkan password yang baru dan hasil akan di perlihatkan pada Gambar 10.

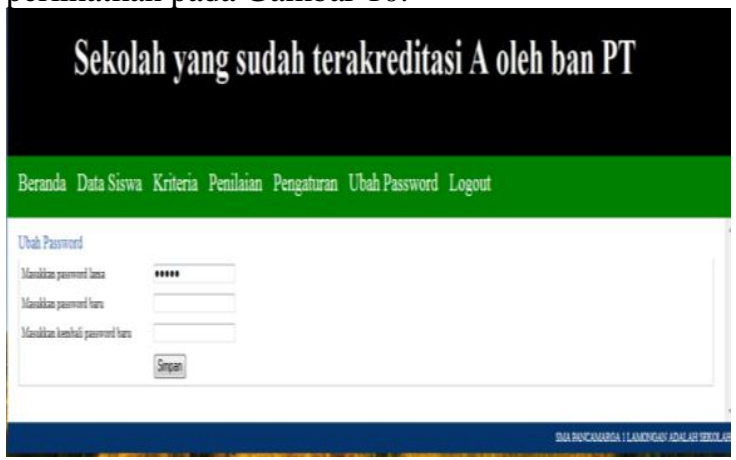

Gambar 10. Halaman Ubah Password

\section{KESIMPULAN}

Berdasarkan hasil penelitian yang dilakukan oleh penulis, serta penjelasan dan analisa dari uraian bab-bab sebelumnya, maka dapat disimpulkan dari proses pembuatan dan proses uji coba sistem pendukung keputusan ini adalah:

- Telah terbangunnya sistem pendukung keputusan penjurusan siswa pada Sma Pancamarga 1 Lamongan ,menggunakan metode fuzzy.

- $\quad$ Metode Fuzzy dapat diimplementasikan pada sistem pendukung keputusan ini dengan memberikan sebuah kriteria, subkriteria dan data nilai Minmax berdasarkan data yang didapat saat melakukan penelitian.

- Hasil akhir dari penelitian ini adalah membuat suatu sistem yang dapat membantu untuk membantu siswa dalam merekomendasikan jurusan ke universitas jika mau meneruskan ke jenjang yang lebih tinggi

\section{REFERENSI}

[1] Andi, 2013, Java Script Source Code, Andi, Yogyakarta.

[2] Andi, 2011, Hot Tip \& Trik PHP Programming, Andi, Yogyakarta. 
[3] Rekomendasi Pemilihan Jurusan, 2015, Penyusunan penjurusan siswa (SPK), http://pemerintah.net/pemilihan rekom -sasaran-belajar -siswa -spk/, diakses tanggal 8 mei 2017 pukul 21.00.

[4] Adminitrasi Pemerintah, 2015, Pengisian SPK: Kolom Kegiatan, http://pemerintah.net/pengisian-skp-kolomkegiatan/, diakses tanggal 8 mei 2017 pukul 20.00 .

[5] Dadang Sudarman, Prihastuti Harsani, Arie Qur'ania, 2014, Aplikasi Sistem Penilaian Kinerja Pegawai Dengan Metode Fuzzy
Berbasis Web, Jurnal ilmu computer, matimatika dan ilmu pengetahuan alam universitas Pakuan, Bogor.

[6] Muhammad Nur Alim, 2013, Metode Fuzzy Mamdani, Pada Kebun Kelapa sawit di daerah Polowali Mandar, Skripsi, Universitas Hassanudin Fakultas Ilmu Sosial dan ilmu politik, Polowali Mandar.

[7] Dwi Meutia Agustina, M.J.Dewiyani Sunarto, Kurniawan Jatmika, 2013, Sistem pendukung keputusan dan diklat Surabaya, Junal Jurusan Sistem Informasi STMIK STIKOM Surabaya, Vol 2 No 2. 
Halaman Sengaja Dikosongkan 